This is an electronic reprint of the original article. This reprint may differ from the original in pagination and typographic detail.

Author(s): Tervo, Hannu; Haapanen, Mika

Title: The nature of self-employment: how does gender matter?

Year: $\quad 2010$

Version:

Please cite the original version:

Tervo, H., \& Haapanen, M. (2010). The nature of self-employment: how does gender matter?. International Journal of Entrepreneurship and Small Business, 9(3), 349-371. https://doi.org/10.1504/ijesb.2010.031926

All material supplied via JYX is protected by copyright and other intellectual property rights, and duplication or sale of all or part of any of the repository collections is not permitted, except that material may be duplicated by you for your research use or educational purposes in electronic or print form. You must obtain permission for any other use. Electronic or print copies may not be offered, whether for sale or otherwise to anyone who is not an authorised user. 


\title{
The nature of self-employment: how does gender matter?
}

\author{
Hannu Tervo (professor) and Mika Haapanen (acting professor) \\ School of Business and Economics \\ PO Box 35 FIN-40014 University of Jyväskylä \\ emails: htervo@econ.jyu.fi mphaapan@econ.jyu.fi
}

\begin{abstract}
This paper analyses female and male entrepreneurship and the differences between them in Finland. The female self-employment rate is clearly lower than that of male self-employment in Finland. The paper shows that differing behaviour accounts for differing rates of self-employment between females and males. The predicted earnings differential between self-employment and paid-employment has a divergent effect on the probabilities of self-employment. For males, it is positive, as expected. For females, it has no effect, which accentuates the other motives they have for selfemployment. Both spouse and family are found to have bigger effects on female selfemployment than on male self-employment. Yet personal characteristics are behind entrepreneurship for both sexes. Regional characteristics are more important for male than female self-employment. The analysis is based on a structural probit model and a large register-based data set which represents a 7\% random sample of all Finns in 2001.
\end{abstract}

KEY WORDS: self-employment, entrepreneurship, gender differences, expected earnings, structural probit

JEL CLASSIFICATION: J16, J24, J31, L26 


\section{Introduction}

In all countries, there are fewer female than male entrepreneurs, albeit in many countries females represent the fastest growing segment among the self-employed (Parker, 2004; Verheul, van Stel and Thurik, 2006). The reasons that lead women and men to be self-employed can be very different. Although an increasing number of studies have analysed female self-employment and gender differences in selfemployment, a drawback shared by many studies is that they ignore relative earnings as a determinant of female self-employment (cf. Parker, 2004).

According to the Knightian utility maximizing paradigm, individuals choose the alternative that offers the greatest expected utility (Knight, 1921). Most economic research on self-employment and entrepreneurship is derived from the model according to which a rational worker chooses self-employment if the expected utility exceeds that of paid-employment. These utilities are affected by earnings; personal characteristics, such as social background, education and experience; and environmental factors. Family situation may also be an important factor, especially in the case of females. Primarily due to child-care concerns, men and women may have different occupational strategies.

For females, entrepreneurship may offer a meaningful career opportunity allowing them better possibilities to combine work and family activities than offered by wage work (Arenius and Kovalainen, 2006). Carr (1996) even argued that a theory of selfemployment that applies to women must incorporate family characteristics, including marital status, parental status, and ages of children. Several studies show that female and male entrepreneurs also differ in many respects. For example, self-employed females often work in different sectors than self-employed males. Female entrepreneurs have been found to be more educated (Cowling and Taylor, 2001) and older (Devine, 1994) than male entrepreneurs. Rosti and Chelli (2005) found that Italian women often enter self-employment due to inactivity or unemployment.

Of the factors that cause the utility from self-employment to exceed that from paidemployment, the earnings are plausibly one of the most influential. The hypothesis is that the higher the earnings differential between self-employment and paid-employment, the more likely individuals are to become entrepreneurs. The empirical results are, however, inconclusive: relative earnings do not play a clear-cut role in explaining selfemployment choice. ${ }^{1}$ Georgellis and Wall (2005) found that men and women respond 
differently to earnings differentials between paid-employment and self-employment: earnings differentials are found to be important for men but not for women in Germany. Self-employed women are less likely to be in high-paying occupations and industries than self-employed men (Devine, 1994; Clain, 2000; Hundley 2001). Large earnings differential between self-employed men and women are also found to be due to differential effects of housework and family responsibilities (Hundley, 2001). After controlling for differences in some personal characteristics, Moore (1983), nevertheless, found that in self-employment, female/male earnings ratios are much lower than in paid-employment. A different conclusion is that women who choose self-employment have personal characteristics that are less highly valued by the market than women who choose wage- and salary-employment, while the reverse is true for men (Clain, 2000). Burke, FitzRoy and Nolan (2002) found that the impact of entrepreneurial ability on the performance of self-employed individuals is different for males and females. For male entrepreneurs, post-compulsory education and professional training are positively associated with the value of the business and the number of employees hired, while for female entrepreneurs the same determinants of entrepreneurial ability have insignificant effects on their performance.

An important question, which relates to the motives for self-employment, concerns the relative strength of pull and push factors. Are individuals pushed or pulled into selfemployment? Is it market pull and higher expected earnings which dominate or are individuals pushed into entrepreneurship because nothing else is available? Are there gender differences? Existing research on the "push-pull" debate has not provided conclusive answers, although many studies support the role of push factors (e.g. Storey, 1991; Earle and Sakova, 2000; Moore and Mueller, 2002; Ritsilä and Tervo, 2002; Tervo, 2006). A recent Finnish study, however, suggests that unemployment is no longer an important route to entrepreneurship (Heinonen et al, 2006). Results from the Global Entrepreneurship Monitor research would show that necessity as a primary entrepreneurial motive is low in Finland, but relatively large share of individuals possess motives of both opportunity and necessity at the same time (Heinonen, Kovalainen and Pukkinen, 2006). Interestingly, sociological theories suggest that lowwage workers are pushed into entrepreneurship, whereas high-wage workers are pulled into entrepreneurship by attractive opportunities (Clain, 2000). As women receive lower wages than men, the theory would suggest that women, especially, are pushed into selfemployment. Indeed, Hughes (2003) argued that push factors have been underestimated 
in explaining rising self-employment among women: restructuring and downsizing have eroded the availability of once secure jobs in the public and private sector. The promise of independence, flexibility and opportunities is not that important in this situation.

This paper analyses the nature of female and male self-employment by applying the structural probit model which, since the pioneering work by Rees and Shah (1986), has been applied in many subsequent works (e.g., Dolton and Makepeace, 1990; Taylor, 1996; Johansson, 2000; Georgellis and Wall, 2005; Leung, 2006; Hammarstedt, 2006). Most empirical studies have focused on men's self-employment decisions and, thus, there is a distinct lack of comparable work on the self-employment decisions of women, especially work which also analyses the role of expected earnings (see, however, Georgellis and Wall, 2005; Leung, 2006). A number of studies have used pooled data on men and women, using only a dummy variable to capture gender differences. This is not sufficient, since the effects of many factors such as family and relative selfemployment earnings may differ between females and males. In the present study, separate parameters are estimated jointly for females and males using interaction variables. This allows us to test whether an effect observed for any explanatory variable is gender-dependent.

Our analysis is based on a data set taken from various registers kept by Statistics Finland. The data set represents a 7\% random sample of all Finns from 2001. It includes rich information on individuals, their families and parents, jobs, dwellings and incomes, and their regions of residence. Due to its nature, the data are very reliable. For example, the measurement of income, which is based on the tax files of the National Inland Revenue Board, offers an excellent starting point for analysing how relative financial returns affect the choice between self-employment and paid-employment among females and males. Our standpoint is, however, wider than in any other previous study seeking to explain gender differences in self-employment. Our data set also enables us to compare, for example, the importance of an individual's creativity, spouse's characteristics, parental background and many environmental factors in occupational choice.

The rest of the paper is organized as follows: Our model, data and variables are described in Section 2. The estimation results are presented in Section 3. Overall comments on the study conclude the paper. 


\section{Model, data and variables}

\subsection{Model}

According to our model, an individual chooses to work in paid-employment or to be self-employed. Which alternative is selected is based on comparison of their relative utilities. The individual will become self-employed if the utility exceeds from so doing the utility gained from paid-employment. Each of these utilities is affected by the individual's background, family situation, parental background and local labour market characteristics as well as the earnings (s)he expects to obtain from each alternative. As discussed in the introduction, these characteristics may affect the utilities of women and men differently. ${ }^{2}$

Hence, we assume that the net benefit of working in self-employment for an individual $i$ is:

$$
U_{i S E}-U_{i E}=\alpha^{j}\left(\ln Y_{i S E}-\ln Y_{i E}\right)+X_{i} \beta^{j}+\varepsilon_{i}, \quad j=f, m
$$

where $U$ represents the utility that the individual can expect to receive from selfemployment $(S E)$ and from paid-employment $(E)$. On the right-hand side the first term is the difference between the logarithms of earnings $Y$ in the two occupational choices, $X$ is a vector of the characteristics (same for both sexes) that influence the individual's choice between self-employment and paid-employment, $\alpha^{j}$ and $\beta^{j}$ are parameters or vectors of parameters to be estimated, $j$ indexes gender ( $f=$ female, $m=$ male), and $\varepsilon$ is a random error term. By assuming that the error term is normally distributed, the probability that an individual will choose to be self-employed, $\operatorname{prob}\left(U_{S E}-U_{E}>0\right)$, can be estimated by probit analysis.

The estimation, however, involves some difficulties that need to be addressed. First, as the determinants of female and male self-employment are likely to differ, it is important to allow for different parameter estimates for females and males. This could be done by estimating the model separately for females and males, as in Georgellis and Wall (2005). However, it would not enable us to test the statistical significance of the gender differences. Instead, we estimate the model jointly for both sexes but at the same time interact all the explanatory variables with a gender dummy. 
Second, calculation of the relative earnings differential requires estimates for earnings in paid-employment and self-employment; however, for each individual they are observed only for the particular alternative chosen. For example, for the self-employed, the census data do not provide any direct measure of what (s)he would have earned in paid-employment instead. Ordinary least squares estimates from the two subsamples $(S E, E)$ will not necessarily result in unbiased earnings estimates, because individuals choose the alternative that suit them best. Thus, the subsamples may not be randomly selected from the full sample (the so-called self-selection problem, see Heckman, 1979). Therefore, before the estimation of (1), selectivity-corrected earnings functions are estimated separately for the self-employed and paid-employees by using the Heckman two-step approach:

$$
\begin{aligned}
& \ln Y_{i S E}=M_{i} \delta_{S E}^{j}+\gamma_{S E}^{j} \lambda_{i S E}+\mu_{i S E} \\
& \ln Y_{i E}=M_{i} \delta_{E}^{j}+\gamma_{E}^{j} \lambda_{i E}+\mu_{i E}
\end{aligned}
$$

where $M(\neq X)$ is a vector of the variables influencing earnings, and $\lambda_{S E}$ and $\lambda_{E}$ are the inverse Mills ratios to correct for selectivity in each type of occupation. They are computed using a reduced-form probit model, in which the self-employment decision is explained by all variables in $M$ and $X$, but which are again interacted with a gender dummy. Mincer-type earning equations (2) and (3) are used to predict the earnings from self-employment and paid-employment, respectively. Thus, the estimations proceed in three stages, the final step being the estimation of the structural probit, in which the unobserved values of $\ln Y_{S E}-\ln Y_{E}$ in equation (1) are replaced by the predicted values.

Third, to ensure that the estimated parameters are identified, variables that appear in $X$ but not in $M$ should be variables that affect the self-employment decision but not earnings. Similarly, variables that appear in $M$ but not in $X$ should be variables that only affect earnings and not the choice to become self-employed. Our earnings equations include variables that describe personal and regional characteristics; characteristics related to one's family, spouse, parents and house property are not included. In the estimation of the structural probit equation, two dummies describing work experience have been left out to avoid a multicollinearity problem. In consequence, work experience affects the probability of self-employment only through earnings. The results may be sensitive to the choice of exclusion restrictions (cf. Johansson, 2000). This is 
due to multicollinearity problems easily related to the estimation of the structural form probit.

One difficulty still remains in the testing of gender differences. Since the structural probit model (1) is estimated in three steps, the standard errors of the parameters reported by statistical packages, such as Limdep or Stata, are incorrect. Previous selfemployment studies have ignored this problem (e.g. Georgellis and Wall, 2005; Leung, 2006). In the present paper, the statistical testing is based on a nonparametric bootstrap method (see Davidson and Hinkley, 1997; Cameron and Trivedi, 2005, Ch. 11). That is, the parameters are estimated from 1,000 random samples (with replacement) drawn from the original data, after which robust estimates of standard errors are computed using the empirical distributions of the parameters.

\subsection{Sample and data source}

The data set used in the analysis is based on various registers kept by Statistics Finland. We use a $7 \%$ random sample of all individuals who were permanent residents in Finland in 2001. By using the personal identifier, data from various sources have been merged. In addition, data on spouses and parents have also been merged for every individual. ${ }^{3}$ As a result, the data set includes numerous variables from the Longitudinal Census File, Longitudinal Employment Statistics and other registers from the period 1970-2002. In the present cross-sectional analysis, the occupational choice in 2001 is investigated.

The analysis is directed at the population of working age, 18-64 years, who were either in paid-employment or in self-employment in 2001. Those working in the agricultural sector (NACE rev. 1, Class A 01) have been removed. ${ }^{4}$ They number 5,094. The size of the working sample is 146,430 , of which 72,150 are women and 74,280 are men. Compared with the initial sample of 149,238 , the number of observations is slightly reduced because certain variables used in the analysis have missing values and some individuals had no income in 2001. 


\subsection{Variables}

\section{Self-employment}

The dependent variable in the choice by occupational type is a binary variable, assigned the value 1 if the individual is self-employed and 0 if (s)he is a wage-worker (see Table I). This piece of information is based on the definitions used by Statistics Finland (Statistics Finland, 2001). The self-employed (entrepreneurs) are defined as individuals of working age who during the last week of the year 2001 had a self-employed individual's pension insurance (YEL) and are not registered unemployed or doing their military or non-military service. Accordingly, having self-employed pension insurance is the main criterion. This is required if self-employment has continued for at least four months and entrepreneurial income exceeds an annually specified limit. If an individual is also in an employment relationship, it is required that her/his entrepreneurial income exceeds her/his wage income. The category of entrepreneurs also comprises unpaid family members (who are not wage-earners). In all, our definition of self-employment corresponds to the definitions used in other Finnish studies; see, e.g., Johansson (2000) or Hyytinen and Ilmakunnas (2006). The number of self-employed is 11,296, of which $3,757(33 \%)$ are female and 7,539 male. The self-employment rates are 5.2\% and $10.1 \%$, respectively. Thus, the rate for males is nearly twice as high as it is for females.

\section{$==$ Table $\mathrm{I}==$}

\section{Earnings}

The measure of income is based on the tax files of the National Inland Revenue Board for income subject to state taxation in 2001. Hence, the measure of income is both more accurate and more reliable than the measures used in interview-based studies. Income under-reporting by the self-employed is a typical problem encountered in many previous studies (cf. Parker, 2004). Our income measure is the difference in logarithms between annual income subject to state taxation and three types of transfer payments, viz. unemployment benefits, daily and maternity allowance, and home care allowance. Income subject to state taxation includes wage and entrepreneurial income as well as social security benefits. ${ }^{5}$

To obtain expected earnings in both occupations for each individual, two selectivitycorrected earnings equations are estimated using our income measure; see equation (2) 
and (3) above. Interaction variables are used to derive separate parameter estimates for females and males. Because the earnings equations are not the focus of this paper, the results are not presented here. The estimates are merely used to compute the relative earnings differential for each individual.

\section{Personal characteristics}

In addition to the predicted earnings differential, we use an exhaustive number of other explanatory variables which are broadly categorized into six groups (see Table I). Personal characteristics include age, work experience, mother tongue, and field and level of education. Age and work experience are usually expected to be important both for the choice between paid- and self-employment and earnings (Parker, 2004). The effect of age may be non-linear, for which reason both age and age-squared are included. Language differentiates, on the one hand, native Finns from a tiny minority of ethnic immigrants and, on the other hand, the Swedish-speaking minority from the Finnish-speaking majority. Entrepreneurship is often the only possibility for immigrants, for which reason they are likelier than natives to be self-employed (Parker, 2004). The level of immigration is not, however, very high in Finland. Finland is a bilingual country where Finnish is the dominant language, but Swedish is the first language of a significant segment of the population mainly along the southern and

western coastlines. Institutional support for the Swedish-speaking minority has traditionally been strong (Liebkind, Broo and Finnäs, 1995). The Swedish-speaking community with its shared language, culture and social capital may affect the choice between paid- and self-employed.

The field of education reveals individual's educational orientation. Six dummy variables are used to determine the most important fields of education. In addition, three dummy variables are used to describe the level of education. Unlike in previous studies, the highest level of education has been divided into lower-level and higher-level tertiary education. The Finnish results (e.g. Johansson, 2000; Niittykangas and Tervo, 2005) suggest that individuals with a higher level of education have a lower probability of being self-employed. In Finland, more women than men enter higher education. Education increases both an individual's human capital and her/his earnings capacity in paid-employment. 
Three variables are used to describe an individual's creativity. To our knowledge, these variables have not been used in previous analysis of self-employment. The Schumpeterian entrepreneur is the prime mover in economic development, and her/his function is to innovate (Casson, 2003). Schumpeter (1934) viewed the entrepreneur as a rare, unusual creature driven by instinctual motives. Lucas (1978) stated that more able individuals become entrepreneurs and the rest become workers. This leads to an expectation that the more creative an individual is, the more likely (s)he is to become an entrepreneur. On the other hand, knowing that individuals who would otherwise prefer to work in paid-employment are frequently pushed into self-employment, especially if paid-employment opportunities for them remain low, creativity is not inevitably the most pertinent determinant of entrepreneurship. Our creativity variables are based on Florida's (2002) definition of the creative class, which is defined according to occupational data. These people are not necessarily highly educated but work in creative, innovative jobs. The "creative core" includes occupations such as physicists, architects, life science professionals and teaching professionals; "creative professionals" include occupations such as managers, matrons, ward sisters, legal professionals and trade brokers; and "bohemians" include occupations such as writers, creative and performing artists and photographers.

\section{Family characteristics}

It is important, especially in relation to female entrepreneurship, that family characteristics are considered in analysing the choice between paid- and selfemployment. Family support may be assumed to help self-employed individuals in running the business. Family characteristics may also constrain the choice between selfand paid-employment. Especially for women, self-employment may be a flexible strategy to accommodate the competing demands of family and work (Carr, 1996). On the other hand, married people with children may be unwilling to take the risks associated with entrepreneurship.

Our family variables comprehensively describe the individual's family situation, marital status and children. Two variables describe whether the individual is married or cohabiting and one further variable reveals whether (s)he is a single parent or not. Four variables describe the children in the family. In addition to a variable measuring the number of children, three dummy variables differentiate families whose youngest child is less than 3 years old, 3-6 years old and older than 7 years. Women with young 
children may opt for self-employment because of its flexibility and autonomy, provided they have other resources to start their own businesses. However, the availability of public child care is good in Finland and its uptake is also very high. Finally, a dummy differentiates from others those cohabiting couples who have children that are not common.

\section{Spouse's characteristics}

Like family characteristics, spouse's characteristics may be important especially for females. A spouse can help in many ways in the starting phase of the business as well as in its running phase. Intra-household influences such as spouse's type of employment may also affect an individual's observed type of employment (Brown, Farrel and Sessions, 2006). Having a working spouse enhances the probability of self-employment (Blanchflower and Oswald, 1990; Bernhardt, 1994).

We are able to control for spouse's activity, field and level of education and income. A potentially important variable is the one which determines whether a spouse is selfemployed or not. Typically, individuals who have self-employed spouses have higher self-employment rates. Marriage may be a sorting mechanism with respect to selfemployment potential: a self-employed couple might be operating a family business or the presence of a self-employed spouse may enable intra-family flows of financial or human capital, thereby easing an individual's transition into self-employment (Bruce, 1999). The phenomenon of "assortative mating" may also offer an explanation for the similarity of employment status within couples (Brown et al., 2006). The other dummies describing spouse's activity determine whether an individual is a wage-earner, student, retired or unemployed. The education variables are similar to the variables presented above. Finally, a spouse's financial situation is measured by her/his wage income.

\section{Parents' characteristics}

Parental background may account for the choice between self- and paid-employment. Intergenerational transmission in self-employment has been shown to be a strong phenomenon (e.g., Lentz and Laband, 1990; Laferrère and McEntee, 1995; Niittykangas and Tervo, 2005). Children from self-employed families are more likely to perceive such a career as more acceptable than working for someone else. They possess a kind of entrepreneurial human capital or cultural inheritance, as they have been able to observe 
their self-employed parents in their childhood and youth. They may also have gained practical business experience by working in the business.

In addition, parental background may provide self-confidence and social support. For Finland, Niittykangas and Tervo (2005) showed that many sons in self-employed families continue in their parent's footsteps, while daughters in these families do not enter the business as often. In addition to this gender difference, the data enable us to investigate whether there are differences between the relative impact of the father and mother: we use two dummies to describe father's and mother's self-employment history. Dunn and Holtz-Eakin (2000) found that having one parent self-employed has a strong positive effect on the probability of men's self-employment. They also found that the probability of a son becoming self-employed is higher if his father rather than his mother is self-employed. They do not, however, consider female self-employment. In addition to these parental background variables, we also have dummies which measure both father's and mother's educational level.

\section{House property}

Many studies show that the probability of self-employment increases with the individual's net worth (e.g. Evans and Jovanovic, 1989; Evans and Leighton, 1989). Entrepreneurial activity is restricted by liquidity constraints. Two variables measure household wealth. The first shows whether an individual is an owner-occupier of a house or a flat, and the second whether (s)he owns a summer cottage or not.

\section{Regional characteristics}

Regions typically differ with regard to entrepreneurship, including the case of Finland. An individual's region of residence may be a significant determinant of both earnings and the choice between self- and paid-employment. In the analysis, we use five dummies to denote an individual's sub-region of residence. This categorization is based on a comparatively new regional classification created in Statistics Finland (see Kuntaliitto, 2005, Appendix 2). A sub-region consists of several municipalities and represents local labour market reasonably well. Their number is altogether 82 , of which 4 belong to the metropolitan region, 7 are classified as many-sided university regions, 14 as regional centres, 12 as industrial centres, 28 as rural sub-regions and the rest, 17, are classified as sparsely-populated sub-regions. Besides this categorization, a dummy is used to differentiate whether an individual's dwelling place is an urban or a scattered 
settlement. Each sub-region has both types of settlements - even the metropolitan region has scattered settlements while sparsely-populated sub-regions have urban settlements.

In addition to these dummies, three complementary variables describing regional characteristics are used. First, it is important to differentiate between individuals who are residing in their regions of birth from those who are not. Second, we measure the size distribution of enterprises in the sub-region. Several studies have indicated a strong positive relationship between business formation rates and the share of small firms in regions (e.g., Reynolds et al., 1994; Armington and Acs, 2002; in Finland Niittykangas et al., 1994). The seedbed hypothesis assumes that the main determinant of selfemployment is the local industrial structure, through spin-off effects. Not all places are alike in their potential to generate entrepreneurship, partly because the possibilities for the entrepreneurial learning process differ between regions (Tervo and Niittykangas, 1994). Role models are also important here. Regions with strong traditions of entrepreneurship may be able to perpetuate them over time and across generations (Parker, 2004). Individuals who have experience in small firms, either as workers or as members of an entrepreneur family, will be more likely to set up in business than other individuals (Storey, 1994). Third, we measure the rate of employment in the sub-region. Demand conditions may also account for regional variations in entrepreneurship. If employment opportunities remain low in the local labour market, individuals who would otherwise prefer to work in paid-employment are pushed into establishing their own businesses (Ritsilä and Tervo, 2002).

\section{Results}

Coefficients as well as marginal effects estimated for both females and males are presented in Table II. The table also includes information on which differences between females and males are statistically significant. That is, it tells us whether an effect observed for any explanatory variable depends on gender.

$==$ Table II $==$

To begin with, the coefficient of the earnings differential is positive for males and insignificant (although negative) for females. Accordingly, a rise in a male's predicted earnings as self-employed relative to his earnings as wage earner will increase his 
probability of being self-employed, while for females this has no effect (or if it has, it may even be negative). For males, the result is as expected, although the size of the effect remains lower than expected. The marginal effect is 3.9\%: a unit increase in the $\log$ differential is estimated to increase the self-employment rate by nearly four percentage points when calculated at the sample means. For females, the result as such is not surprising. Georgellis and Wall (2005) also found that the predicted earnings differential is not significant for females, while Leung (2006) found that it is more important for males than females.

Our finding supports the hypothesis that many non-pecuniary benefits compared with pecuniary benefits might be more important for female entrepreneurs. The finding also corresponds with the negative sample selection term found in the estimation of the earnings equation. Individuals may turn to self-employment if they have no other choices. Lower or nil earnings in paid-employment reduce the opportunity cost of selfemployment thus pushing individuals into self-employment, especially if they can reconcile their other aims related to working life, as might be the case for females.

Most of the variables describing personal characteristics prove to be important in the structural probit. For males, age has a non-linear effect on the probability of being selfemployed, while for females the result is not significant. If a male does not speak Finnish as his mother tongue, his probability for self-employment increases. In particular, being an immigrant - whose native language is other than Finnish or Swedish - increases this probability: the estimated marginal effect is as high as $7.8 \%$. Field of education has opposite effects for females and males. Teacher and humanistic education (eduother) is the only category to have an effect of the same sign (negative). Business and health education have a notable effect for males: the probability of being self-employed increases as much as $7.9 \%$ if a male's field of education is health or welfare and $3.1 \%$ if it is business or social sciences. For females, the equivalent marginal effects are $-0.8 \%$ and $-0.7 \%$, respectively.

The results on the level of education confirm earlier Finnish results according to which individuals with a high level of education have low probabilities of being selfemployed. Interestingly, females and males differ in this. If a male has a post-graduate degree or a doctorate, his probability of being self-employed decreases by $-6.0 \%$, but for a female the estimated marginal effect is slightly positive, $0.6 \%$ (although insignificant). The difference between the estimated effects is significant. 
Working in creative jobs seems to be related to self-employment, which finding supports the Schumpeterian idea of the innovative entrepreneur. If an individual is "a creative professional", as defined by Richard Florida (2002), then the probability of self-employment increases by $3.9 \%$ for males and $2.5 \%$ for females. Being "a bohemian" also increases the probability of self-employment, as much as $5.5 \%$ for males and $3.7 \%$ for females. Belonging to "a creative core" has, however, a dissimilar effect: for females the estimated coefficient is insignificant, and for males it is significantly negative.

Being married increases the probability of self-employment for both sexes, but cohabitation outside of marriage decreases it. If an individual is a single parent, her/his probabilities for self-employment decrease. For females, the effect is stronger, the marginal effect being $-1.6 \%$. Children do not have statistically significant effects on a parent's probability of self-employment, except for those females who have children younger than three years old. The probability of self-employment increases for such women. The probability of self-employment also increases if a male is married, or is cohabiting with a partner who has children of her own. Consequently, we obtain only weak support for the hypothesis that females who have children under school age would enter self-employment in order to accommodate the competing demands of family and work (Carr, 1996). Finnish women tend to resort to public child care, which is available for everyone.

If an individual has a self-employed spouse, her/his probability of also being selfemployed increases markedly. Interestingly, the size of the effect differs by gender: for males the marginal effect is $17.0 \%$, while for females it is "only" $4.5 \%$. Accordingly, if a husband is self-employed, in many cases his wife is also in business as an entrepreneur or as an unpaid family member, but the reverse does not take place as often. For both sexes, the probability of self-employment decreases if a spouse is a wage earner, student, retired or unemployed. A wife's field of education does not affect her husband's probability of self-employment, while a husband's field of education matters more: if a husband has a technical or agricultural education, his wife's probability of being self-employed decreases. The results are, however, somewhat controversial, since the differences between the estimated coefficients for males' and females' variables are not quite statistically significant. More important are the diverging effects of a spouse's level of education. For males, effects cannot be found, 
while for females, the probability of being self-employed increases the higher her husband's level of education. If a husband has an academic education, his wife's probability of self-employment increases by as much as $3.0 \%$. Spouse's income does not affect the probability of an individual of either sex being self-employed.

Parental background seems to have significance for both sexes. If an individual is from a self-employed family, her/his probability of self-employment increases markedly. For boys, however, this effect is stronger than it is for girls. This result corresponds with earlier Finnish results (Niittykangas and Tervo, 2005). A new result is that a father's effect is greater than a mother's for sons, while the reverse is true for daughters. A further interesting result is that parents' educational background does not have a statistically significant effect on boys' probability of self-employment, while for girls some effect can be found. In particular, if a father has a higher education, his daughter's probability of being self-employed increases.

House property has influence on both sexes, but the effect is greater for males. The probability of self-employment increases by $2.2 \%$ if a male resides in his own house, and by $2.7 \%$ if he owns a summer cottage. For females, the effects are smaller.

Regional features have only a small effect on females' self-employment, whereas they matter more for males. As expected, the probability of self-employment increases for males if the regional environment is dominated by small enterprises: the estimated coefficient on the dummy measuring the average size of enterprises in the sub-region is negative. For females, it is also negative, but not significant. The variable measuring the employment rate in the sub-region has no significance. Thus, contrary to expectations, local labour market conditions do not seem to have an effect on self-employment. However, collinearity between this and other regional variables may be responsible for this result. If males reside in an urban settlement, the probability of self-employment decreases by $4.0 \%$, while for females there is no significance. Furthermore, the regiondummies suggest that males' probabilities for self-employment are lower the more advanced the sub-region, while for females these dummies do not show significance. Finally, if males reside in their region of birth, their probability of self-employment increases, whereas for females this has no significance. Obviously, men perceive selfemployment as an alternative to out-migration, if wage work is scarce in their region, while women are more likely to leave the region. 
To summarize, our results indicate that there is considerable variation between females and males in how various characteristics affect the choice of occupation, although many variables behave alike. In Table III, the maximum and minimum effects of each category of variables on the probabilities of self-employment are presented. For each category, the most favourable and unfavourable situations for self-employment are sought and the probabilities for self-employment in these cases are calculated, while the remaining variables are kept at their means. We also calculated the range between these probabilities and divided the range by the average probability of being self-employed, taking into account the fact that females have a half lower probability of being selfemployed compared to males. ${ }^{6}$

The calculations show that personal characteristics form the most important category for both males and females. In the most favourable situation for self-employment, a male's probability of being self-employed is as high as 0.58 and a female's probability, 0.22 , while in the most unfavourable situation these probabilities are close to nil. Spouse's and parents' characteristics are also important, but family characteristics do not have much effect. It is, however, noticeable that the relative significance of both family's and spouse's characteristics is bigger for a self-employed female than for a self-employed male. Table III also confirms our earlier finding that regional characteristics do not have much importance for female self-employment as they do for male self-employment.

\section{$==$ Table III $==$}

There are many differences between the coefficients for males and females in the structural probit equation and in the average values of their respective variables. The gap between females and males in the probabilities for self-employment may be due to the various characteristics having divergent effects on the incidence of self-employment or due to differences in the average values of these characteristics. To analyse this, we calculated the hypothetical probabilities of self-employment for both females and males in different cases (Table IV). When the coefficients for males in the structural probit equation are used for females we obtain the probability of 0.118 , which is even bigger than the average predicted probability for males, 0.102. Again, when the coefficients for females are used for males we obtain the probability of 0.057 , which is quite close to the average probability for females, 0.052 . In consequence, these results would suggest 
that the gap in self-employment rates between females and males is due rather to differing behaviour than to differing characteristics between the sexes.

$==$ Table IV $==$

\section{Conclusions}

The paper provides a large body of evidence on the differing nature of female and male self-employment. The female self-employment rate is clearly lower than the male selfemployment rate in Finland. The reasons that lead women and men to be self-employed differ and end in a gap in their respective self-employment rates. We would direct attention especially to the four following points:

First, the predicted earnings differential has a divergent effect on the probabilities of self-employment for females and males. A rise in male's predicted earnings as selfemployed relative to his earnings as a wage earner will increase his probability of being self-employed, while for females such a rise has no effect. This finding accentuates the importance of other motives for self-employment among women. Both spouse and the family have relatively bigger effects on female self-employment than on male selfemployment. However, personal characteristics underlie entrepreneurship for both sexes.

Second, the environment in which an individual resides has less effect on females' than males' inclinations to be self-employed. In consequence, regional variations in the rate of self-employment are much bigger among men than women in Finland. Obviously, the push factor is stronger among men than women: the worse a region's prospects for paid-employment, the higher its male self-employment rate, while the relationship is not that obvious for females. ${ }^{7}$

Third, as higher expected earnings pull only males into self-employment, the pull factor is also stronger among men than women. Thus, in the case of females, our results do not lend firm support to either the push or pull hypotheses. To simplify, rather than being pushed or pulled into self-employment, females tend to choose self-employment if this is convenient in relation to their family and other situations.

Fourth, role models strongly affect entrepreneurial behaviour. We used three kinds of variables to measure the effect of role models on self-employment: parents' 
entrepreneurship, spouse's entrepreneurship and the size distribution of enterprises in the sub-region (indicating the role which small firms and an entrepreneurial tradition have in the region). All of these variables proved to be very important for the option of self-employment. They have a considerable impact on female self-employment, even if their impact on male self-employment remains much greater. Thus, role models are especially important for male entrepreneurs.

Should women's entrepreneurship be supported? Entrepreneurship opens up possibilities for both sexes; however, self-employment is a much more important option for males than for females. Female entrepreneurship has been emphasised more and more in recent economic debate in Finland, as it has been seen that increasing female entrepreneurial activity leads to more overall entrepreneurial activity and improves employment situation of women. Wilson et al. (2004), however, argue that a strong economic argument for supporting women's enterprise has not yet been presented. If returns to entrepreneurship remain poor, government intervention is not justified, especially if it is encouraging weak individuals into self-employment and creating insecure firms. Economic restructuring is increasingly pushing especially women into marginalized forms of self-employment, although most people would be better off in employment than in self-employment. ${ }^{8}$

But if the labour market is not tight and paid work is not easily available, which is the situation especially in many Finnish rural regions, self-employment may become an important option from the point of view of employment and regional development. Women's entrepreneurship could be advanced not only by removing direct obstacles preventing the decisions to set up a business, but also by trying to affect women's behaviour in the long run. This can be done by tackling traditional gender and behavioural roles and belief systems to channel women into sectors and occupations which offer good opportunities for flourishing entrepreneurship.

\section{Acknowledgements}

The paper is a part of a Research Programme on Business Know-how (LIIKE 2, project no 112116) financed by the Academy of Finland and a part of research project number 120185 also financed by the Academy of Finland. The first author also thanks the Yrjö Jahnsson Foundation for its financial support. 


\section{Notes}

${ }^{1}$ Parker (2004) presents a good survey of these results.

2 Traditionally, the structural probit model, which is being applied here, considers utility differences between self-employment and wage employment, ignoring the utility levels from unemployment. In principle, the model could be extended to include the possibility of unemployment, but for simplicity the extension of the model will not be applied in this comparative analysis of genders. Furthermore, under the assumption of independence of irrelevant alternatives, the comparative utilities of self-employment and wage employment would not change.

${ }^{3}$ The data set was ordered from Statistics Finland where the compilation was also done. Due to data protection legislation, Statistics Finland does not give information which would allow individuals to be identified.

${ }^{4}$ Most self-employment analyses exclude agricultural workers. The concept of selfemployment is vaguer in agriculture than in other industries; farm businesses have characteristics that are very different from non-farm businesses (Blanchflower, 2000; Parker, 2004).

${ }^{5}$ Due to data protection legislation, the highest percentile in the income subject to state taxation is given as a mean in the data. This is, however, unlikely to affect the results.

6 This statistic is comparable to the coefficient of variation in which the standard deviation is divided by the mean.

${ }^{7}$ It should, however, be noted that the role of the push factor in entrepreneurship in Finland is emphasised in an overall analysis of self-employment like this. Had we analysed, e.g., knowledge-based entrepreneurship, the role of pull factors would presumably have been more important.

8 As gender discrimination alters the distribution of entrepreneurial talent between employees and self-employed workers, as Rosti and Chelli (2005) argue, it lowers the opportunity cost of self-employment to women, which gives rise to the prediction that the risk of failure of the self-employed women will increase. 


\section{References}

Van Andersen, K., H. K. Hansen, A. Isaksen and M. Raunio (2006) The geography of technology, talent and tolerance: Nordic cases, Paper to be presented in American Association of Geographers - Annual conference, 9th March, Chicago.

Arenius, P. and A. Kovalainen (2006) 'Similarities and differences across the factors associated with women's self-employment preference in the Nordic countries', International Small Business Journal 24: 31-59.

Armington, C. and Z. J. Acs (2002) 'The determinants of regional variation in new firm formation', Regional Studies 26(1): 33-45.

Bernhardt, I. (1994) 'Competitive advantage in self-employment and paid work', Canadian Journal of Economics 27: 273-289.

Blanchflower, D. G. (2000) 'Self-employment in OECD-countries', Labor Economics 7: 471-505.

Blanchflower, D. G. and A. Oswald (1990) Self-employment and the enterprise culture, in R. Jowell, S. Witherspoon and L. Brook (eds.), British Social Attitudes: The 1990 Report, London: Gower.

Brown, S., L. Farrel and J. G. Sessions (2006) 'Self-employment matching: an analysis of dual earner-couples and working households', Small Business Economics 26: $155-172$.

Bruce, D. (1999) 'Do husbands matter? Married women entering self-employment', Small Business Economics 13: 317-329.

Burke, A. E., F. R. FitzRoy and M. A. Nolan (2002) 'Self-employment wealth and job creation: the roles of gender, non-pecuniary motivation and entrepreneurial ability', Small Business Economics 19: 255-270.

Cameron, A. C. and P. K. Trivedi (2005) Microeconometrics: Methods and Applications. Cambridge: Cambridge University Press.

Carr, D. (1996) ‘Two paths to self-employment? Women's and men's self-employment in the United States, 1980', Work and Occupations 23: 26-53.

Casson, M. (2003) The Entrepreneur. An Economic Theory, 2nd edition. Cheltenham, UK \& Northampton, MA, USA: Edward Elgar.

Clain, S. H. (2000) 'Gender differences in full-time self-employment', Journal of Economics and Business 52: 499-513.

Cowling, M. and M. Taylor (2001) 'Entrepreneurial women and men: two different species?' Small Business Economics 16: 167-175. 
Davidson, A. D. and D. V. Hinkley (1997) Bootstrap Methods and Their Applications. Cambridge: Cambridge University Press.

Devine, T. J. (1994) 'Characteristics of self-employed women in the United States', Monthly Labour Review 117: 20-34.

Dolton, P .J. and G. H. Makepeace (1990) 'Self-employment among graduates', Bulletin of Economic Research 42: 35-53.

Dunn, T. and D. Holz-Eakin (2000) 'Financial capital, human capital and the transition to self-employment: evidence from intergenerational links', Journal of Labour Economics 18: 282-305.

Earle, J. S. and Z. Sakova (2000) 'Business start-ups or disguised unemployment? Evidence on the character of self-employment in transition countries', Labour Economics 7: 545-574.

Evans, D. S. and B. Jovanovic (1989) 'An estimated model of entrepreneurial choice under liquidity constraints', Journal of Political Economy 97: 808-827.

Evans, D. S. and L. S. Leighton (1989) 'Some empirical aspects of entrepreneurship', American Economic Review 79: 519-535.

Florida, R. (2002) The Rise of the Creative Class, and How It's Transforming Work, Leisure, Community and Everyday Life. New York: Basic Books.

Georgellis, Y. and H. J. Wall (2005) 'Gender differences in self-employment', International Review of Applied Economics 19: 321-342.

Hammarstedt, M. (2006) 'The predicted earnings differential and immigrant selfemployment in Sweden', Applied Economics 38: 619-630.

Heckman J. (1979) 'Sample selection bias as a specification error', Econometrica 47: $153-161$.

Heinonen, J., A. Kovalainen, K. Paasio, T. Pukkinen and J. Österberg (2006) From waged work to entrepreneurship - Study on routes from waged work to entrepreneurship in the social and health care sector and among business and technical university graduates (in Finnish), Labour research publications 297, Ministry of Labour.

Heinonen, J., A. Kovalainen and T. Pukkinen (2006) Global Entrepreneurship Monitor 2005 Executive Report Finland. Turku School of Economics and Business Administration, Business Research and Development Centre, Series B 2, Lahti. 
Hughes, K. D. (2003) 'Pushed or pulled? Women's entry into self-employment and small business ownership', Gender, Work and Organization 10: 433-454.

Hundley, G. (2001) 'Why women earn less than men in self-employment', Journal of Labor Research 22: 817-829.

Hyytinen, A. and P. Ilmakunnas (2006) 'What distinguishes a serial entrepreneur', HECER Discussion paper No. 111.

Johansson, E. (2000) 'Self-employment and the predicted earnings differential evidence from Finland', Finnish Economic Papers 13: 45-55.

Knight, F. H. (1921) Risk, Uncertainty and Profit. New York: Houghton-Mfflin.

Kuntaliitto (2005) A survey on structural changes (in Finnish), Local and Regional Government Finland, Helsinki.

Laferrère, A. and P. McEntee (1995) 'Self-employment and intergenerational transfers of physical and human capital: an empirical analysis of French data', Economic and Social Review 27: 43-54.

Lentz, B.F. and D. N. Laband (1990) 'Entrepreneurial success and occupational inheritance among proprietors', Canadian Journal of Economics 13: 563-579.

Leung, D. (2006) The male/female earnings gap and female self-employment, The Journal of Socio-Economics 35(5): 759-779.

Liebkind, K., R. Broo and F. Finnäs (1995) The Swedish-speaking minority in Finland, in Cultural Minorities in Finland. An Overview Towards Cultural Policy, Publications 66, Finnish National Commission for Unesco.

Lucas, R. E. (1978) 'On the size distribution of business firms', Bell Journal of Economics 9: 508-523.

Moore, R. L. (1983) 'Employer discrimination: evidence from self-employed workers', Review of Economics and Statistics 65: 496-501.

Moore, C. S. and R. E. Mueller (2002) 'The transition from paid to self-employment in Canada: the importance of push factors', Applied Economics 34: 791-801.

Niittykangas, H., E. Storhammar and H. Tervo (1994) Entrepreneurship and birth of new firms in local environments (in Finnish), University of Jyväskylä, Centre for Economic Research in Central Finland, Publications 132, Jyväskylä.

Niittykangas, H. and H. Tervo (2005) 'Spatial variations in intergenerational transmissions of self-employment', Regional Studies 39: 319-332.

Parker, S. C. (2004) The Economics of Self-Employment and Entrepreneurship. Cambridge: Cambridge University Press. 
Rees, H. and A. Shah (1986) 'An empirical analysis of self-employment in the U.K.', Journal of Applied Econometrics 1: 95-108.

Reynolds, P., D. J. Storey and P. Westhead (1994) 'Cross-national comparisons of the variation in new firm formation rates', Regional Studies 28: 443-456.

Ritsilä, J. and H. Tervo (2002) 'Effects of unemployment on new firm formation: micro-level panel data evidence from Finland', Small Business Economics 19: 3140.

Rosti, L. and F. Chelli (2005) 'Gender discrimination, entrepreneurial talent and selfemployment', Small Business Economics 24: 131-142.

Schumpeter, J. A. (1934) The Theory of Economic Development. Cambridge, MA: Harvard University Press.

Storey, D. (1991) 'The birth of new firms - does unemployment matter? A review of the evidence', Small Business Economics 3: 167-178.

Storey, D. (1994) Understanding the Small Business. London: Routledge.

Taylor, M. P. (1996) 'Earnings, independence or unemployment: why become selfemployed?' Oxford Bulletin of Economics and Statistics 58: 253-265.

Tervo, H. (2006) 'Regional unemployment, self-employment and family background', Applied Economics 38: 1055-1062.

Tervo, H. and H. Niittykangas (1994) 'The impact of unemployment on new firm formation in Finland', International Small Business Journal 13: 38-53.

Verheul, I., A. van Stel and R. Thurik (2006) 'Explaining female and male entrepreneurship at the country level', Entrepreneurship and Regional Development 18: $151-183$.

Wilson, L., G. Whittam and D. Deakins (2004) 'Women's enterprise: a critical examination of national policies', Environment and Planning C: Government and Policy 22: 799-815. 


\section{TABLE I}

Descriptions of variables and their means

\begin{tabular}{|c|c|c|c|c|c|}
\hline \multirow{2}{*}{ Variable } & \multirow{2}{*}{ Definition } & \multicolumn{2}{|c|}{ Females } & \multicolumn{2}{|c|}{ Males } \\
\hline & & E & SE & E & SE \\
\hline \multicolumn{6}{|c|}{ Dependent variables } \\
\hline Self-empl & 1 if self-employed in 2001, 0 if wage-worker & 0 & 1 & 0 & 1 \\
\hline Lnincome & $\begin{array}{l}\text { In (income subject to state taxation - unemployment } \\
\text { benefit - daily allowance and maternity allowance - } \\
\text { home care allowance) }\end{array}$ & 9.782 & 9.514 & 10.139 & 9.944 \\
\hline \multicolumn{6}{|c|}{ Explanatory variables } \\
\hline Dpredinc & Predicted earnings differential (see Appendix A) & 0.750 & 0.587 & 0.336 & 0.263 \\
\hline \multicolumn{6}{|c|}{ Personal characteristics } \\
\hline Age & Age in years & 40.730 & 45.135 & 39.736 & 45.268 \\
\hline Age2 & Age-squared divided by 100 & 17.878 & 21.346 & 17.060 & 21.408 \\
\hline \multicolumn{6}{|c|}{ Work experience (reference category: work experience less than 5 years in 1987-2000) } \\
\hline Workexp1 & 1 if work experience is $5-10$ years, 0 otherwise & 0.228 & 0.235 & 0.226 & 0.163 \\
\hline Workexp2 & & \multicolumn{3}{|c|}{ Mother language (reference category: Finnish) } & 0.790 \\
\hline Swedish & 1 if native language is Swedish, 0 otherwise & 0.055 & 0.056 & 0.057 & 0.074 \\
\hline Otherlan & $\begin{array}{l}1 \text { if native language other than Finnish or Swedish, } 0 \\
\text { otherwise }\end{array}$ & 0.013 & 0.013 & 0.017 & 0.020 \\
\hline \multicolumn{6}{|c|}{ Field of education (reference category: general education) } \\
\hline Edutrade & $\begin{array}{l}1 \text { if field of education business or social sciences, } 0 \\
\text { otherwise }\end{array}$ & 0.223 & 0.178 & 0.099 & 0.110 \\
\hline Edutechn & $\begin{array}{l}1 \text { if field of education technology or natural sciences, } 0 \\
\text { otherwise }\end{array}$ & 0.086 & 0.082 & 0.453 & 0.390 \\
\hline Eduagric & $\begin{array}{l}1 \text { if field of education agriculture or forestry, } 0 \\
\text { otherwise }\end{array}$ & 0.015 & 0.019 & 0.034 & 0.043 \\
\hline Eduhesoc & 1 if field of education health or welfare, 0 otherwise & 0.194 & 0.142 & 0.023 & 0.034 \\
\hline Eduservi & 1 if field of education services, 0 otherwise & 0.127 & 0.247 & 0.058 & 0.034 \\
\hline Eduother & $\begin{array}{l}1 \text { if field of education teacher education, educational } \\
\text { science, humanities, arts or not known or unspecified, } 0 \\
\text { otherwise }\end{array}$ & 0.086 & 0.051 & 0.040 & 0.020 \\
\hline \multicolumn{6}{|c|}{ Level of education (reference category: primary education) } \\
\hline Interedu & 1 if secondary education, 0 otherwise & 0.413 & 0.468 & 0.461 & 0.425 \\
\hline Lohigedu & $\begin{array}{l}1 \text { if lowest level tertiary education or lower-degree } \\
\text { level tertiary education, } 0 \text { otherwise }\end{array}$ & 0.300 & 0.211 & 0.218 & 0.195 \\
\hline Hihigedu & $\begin{array}{l}1 \text { if higher-degree level tertiary education or doctorate } \\
\text { or equivalent level tertiary, } 0 \text { otherwise }\end{array}$ & 0.101 & 0.084 & 0.105 & 0.057 \\
\hline \multicolumn{6}{|c|}{$\begin{array}{l}\text { Creativity (reference category: other than "creative occupation," see Florida } 2002 \text { or van } \\
\text { Andersen et al 2006) }\end{array}$} \\
\hline Creacore & $\begin{array}{l}1 \text { if occupation is counted among "creative core", } 0 \\
\text { otherwise }\end{array}$ & 0.121 & 0.084 & 0.127 & 0.064 \\
\hline Creaprof & $\begin{array}{l}1 \text { if occupation is counted among "creative } \\
\text { professionals," } 0 \text { if otherwise }\end{array}$ & 0.206 & 0.273 & 0.204 & 0.274 \\
\hline Creabohe & $\begin{array}{l}1 \text { if occupation is counted among "bohemians", } 0 \\
\text { otherwise }\end{array}$ & 0.011 & 0.020 & 0.014 & 0.018 \\
\hline \multicolumn{6}{|c|}{ Family characteristics } \\
\hline Marri & 1 if married or cohabiting, 0 otherwise & 0.774 & 0.867 & 0.706 & 0.820 \\
\hline Cohabit & 1 if cohabiting, 0 otherwise & 0.179 & 0.126 & 0.190 & 0.153 \\
\hline Oneparen & 1 if one-parent family, 0 otherwise & 0.097 & 0.084 & 0.041 & 0.037 \\
\hline Childnum & Number of children in the family & 0.745 & 0.820 & 0.747 & 0.842 \\
\hline Chilyou7 & 1 if youngest child at least 7 years old, 0 otherwise & 0.244 & 0.284 & 0.201 & 0.261 \\
\hline Chilyou36 & $\begin{array}{l}1 \text { if youngest child between } 3 \text { and } 6 \text { years old, } 0 \\
\text { otherwise }\end{array}$ & 0.101 & 0.097 & 0.095 & 0.096 \\
\hline Chilyou12 & 1 if youngest child less than 3 years old, 0 otherwise & 0.075 & 0.070 & 0.108 & 0.087 \\
\hline Chilnoco & $\begin{array}{l}1 \text { if the cohabiting couple has children that are not } \\
\text { common, } 0 \text { otherwise }\end{array}$ & 0.052 & 0.044 & 0.062 & 0.068 \\
\hline
\end{tabular}


TABLE I

Continued

\begin{tabular}{|c|c|c|c|c|c|}
\hline \multirow{2}{*}{ Variable } & \multirow{2}{*}{ Definition } & \multicolumn{2}{|c|}{ Males } & \multicolumn{2}{|c|}{ Females } \\
\hline & & $\mathrm{E}$ & SE & $\mathrm{E}$ & $\mathrm{SE}$ \\
\hline \multicolumn{6}{|c|}{ Spouse's characteristics } \\
\hline \multicolumn{6}{|c|}{ Activity (reference category: not working) } \\
\hline Spouentr & 1 if self-employed, 0 otherwise & 0.066 & 0.264 & 0.026 & 0.155 \\
\hline Spouwagw & 1 if wage-worker, 0 otherwise & 0.507 & 0.396 & 0.514 & 0.489 \\
\hline Spoustud & 1 if student, 0 otherwise & 0.011 & 0.004 & 0.029 & 0.016 \\
\hline Spoupens & 1 if retired, 0 otherwise & 0.056 & 0.076 & 0.025 & 0.034 \\
\hline Spouunem & 1 if unemployed, 0 otherwise & 0.038 & 0.030 & 0.049 & 0.049 \\
\hline \multicolumn{6}{|c|}{ Field of education (reference category: general education) } \\
\hline Sedutrade & 1 if field of ed. business or social sciences, 0 otherwise & 0.070 & 0.098 & 0.155 & 0.181 \\
\hline Sedutechn & 1 if field of ed. technology or natural sc., 0 otherwise & 0.304 & 0.304 & 0.064 & 0.065 \\
\hline \multirow[t]{2}{*}{ Seduagric } & 1 if field of education agriculture or forestry, 0 & & & & \\
\hline & otherw & 0.028 & 0.039 & 0.011 & 0.015 \\
\hline Seduhesoc & 1 if field of education health or welfare, 0 otherwise & 0.016 & 0.024 & 0.135 & 0.147 \\
\hline Seduservi & 1 if field of education services, 0 otherwise & 0.038 & 0.045 & 0.094 & 0.112 \\
\hline Seduother & $\begin{array}{l}1 \text { if field of education teacher education, educational } \\
\text { science, humanities, arts or unknown, } 0 \text { otherwise }\end{array}$ & 0.030 & 0.034 & 0.060 & 0.055 \\
\hline \multicolumn{6}{|c|}{ Level of education (reference category: primary education) } \\
\hline Sinteredu & 1 if secondary education, 0 otherwise & 0.288 & 0.304 & 0.282 & 0.333 \\
\hline Slohigedu & $\begin{array}{l}1 \text { if lowest level tertiary education or lower-degree } \\
\text { level tertiary education, } 0 \text { otherwise }\end{array}$ & 0.161 & 0.188 & 0.214 & 0.225 \\
\hline Shihigedu & $\begin{array}{l}1 \text { if higher-degree level tertiary education or doctorate } \\
\text { or equivalent level tertiary, } 0 \text { otherwise }\end{array}$ & 0.074 & 0.080 & 0.071 & 0.054 \\
\hline Spouinco & Annual wag & 1.757 & 1.575 & 1.134 & 1.154 \\
\hline \multicolumn{6}{|c|}{ Parents' characteristics } \\
\hline Entrfat & $\begin{array}{l}1 \text { if father was self-employed in } 1970,1980 \text { or } 1990,0 \\
\text { otherwise }\end{array}$ & 0.091 & 0.121 & 0.093 & 0.183 \\
\hline Entrmot & $\begin{array}{l}1 \text { if mother was self-employed in 1970, } 1980 \text { or 1990, } 0 \\
\text { otherwise }\end{array}$ & 0.075 & 0.114 & 0.075 & 0.145 \\
\hline \multicolumn{6}{|c|}{ Father's level of education (reference category: primary education) } \\
\hline Fatinedu & 1 if secondary education, 0 otherwise & 0.159 & 0.126 & 0.171 & 0.116 \\
\hline Fathiedu & 1 if tertiary education, 0 otherwise & 0.214 & 0.162 & 0.228 & 0.150 \\
\hline \multicolumn{6}{|c|}{ Mother's level of education (reference category: primary education) } \\
\hline Motinedu & 1 if secondary education, 0 otherwise & 0.141 & 0.107 & 0.154 & 0.095 \\
\hline Mothiedu & , 0 othe & 0.088 & 0.063 & 0.097 & 0.062 \\
\hline \multicolumn{6}{|c|}{ House property } \\
\hline House & 1 if o & 0.677 & 0.804 & 0.684 & 0.823 \\
\hline Sumcott & 1 if owner of a summ & 0.044 & 0.067 & 0.080 & 0.148 \\
\hline \multicolumn{6}{|c|}{ Regional characteristics } \\
\hline Native & $\begin{array}{l}1 \text { if residing in the (NUTS } 3 \text {-level) region of birth, } 0 \\
\text { otherwise }\end{array}$ & 0.576 & 0.583 & 0.625 & 0.670 \\
\hline \multicolumn{6}{|c|}{ Type of (NUTS 4-level) sub-region (reference category: sparsely populated sub-region) } \\
\hline Metropol & $\begin{array}{l}1 \text { if the sub-region belongs to the metropolitan } \\
\text { (Helsinki) region, } 0 \text { otherwise }\end{array}$ & 0.336 & 0.250 & 0.317 & 0.252 \\
\hline Univreg & $\begin{array}{l}1 \text { if the sub-region is a many-sided university region, } 0 \\
\text { otherwise }\end{array}$ & & 0.234 & 0.240 & 0.216 \\
\hline Regcentre & 1 if the sub-region is a regional centre, 0 otherwise & 0.191 & 0.213 & 0.192 & 0.203 \\
\hline Indcentre & 1 if the sub-region is a industrial centre, 0 otherwise & 0.086 & 0.100 & 0.100 & 0.099 \\
\hline Countrys & 1 if the sub-region is rural, 0 otherwise & 0.100 & 0.145 & 0.107 & 0.156 \\
\hline Densepop & $\begin{array}{l}1 \text { if dwelling place in the municipality is urban } \\
\text { settlement, } 0 \text { if scattered settlement }\end{array}$ & 0.890 & 0.830 & 0.876 & 0.780 \\
\hline Firmavsi & $\begin{array}{l}\text { Average size of enterprises in the sub-region (person / } \\
\text { enterprise) }\end{array}$ & 4.821 & 4.571 & 4.791 & 4.521 \\
\hline Emplrate & Employment rate in the sub-region (\%) & 65.085 & 64.061 & 64.885 & 64.020 \\
\hline Number of & servations & 68393 & 3757 & 66741 & 7539 \\
\hline
\end{tabular}

Notes: $\mathrm{E}=$ wage earners, $\mathrm{SE}=$ self-employed. All variables are measured in 2001, except creativity which is based on information on each individual's occupation in 2000. 
TABLE II

Determinants of self-employment: estimates of the structural probit model

\begin{tabular}{|c|c|c|c|c|c|}
\hline \multirow[b]{2}{*}{ Variable } & \multicolumn{2}{|c|}{ Females } & \multicolumn{2}{|c|}{ Males } & \multirow{2}{*}{$\begin{array}{l}\text { Significance } \\
\text { of the } \\
\text { difference }\end{array}$} \\
\hline & Coefficient & $\begin{array}{c}\text { Marginal } \\
\text { effect }\end{array}$ & Coefficient & $\begin{array}{c}\text { Marginal } \\
\text { effect }\end{array}$ & \\
\hline \multicolumn{6}{|c|}{ Earnings differential } \\
\hline Dpredinc & -0.854 & -0.071 & $0.272 *$ & $0.039 *$ & $*$ \\
\hline \multicolumn{6}{|c|}{ Personal characteristics } \\
\hline Age & -0.047 & -0.004 & $0.091 * *$ & $0.013^{* *}$ & $* *$ \\
\hline Age2 & 0.062 & 0.005 & $-0.080 * *$ & $-0.012 * *$ & $* *$ \\
\hline Swedish & 0.088 & 0.008 & $0.109 * *$ & $0.017 * *$ & \\
\hline Otherlan & 0.075 & 0.007 & $0.411 * *$ & $0.078^{* *}$ & * \\
\hline Edutrade & -0.092 & -0.007 & $0.190 * *$ & $0.031^{* *}$ & \\
\hline Edutechn & -0.209 & -0.015 & 0.005 & 0.001 & \\
\hline Eduagric & -0.064 & -0.005 & 0.070 & 0.011 & \\
\hline Eduhesoc & -0.108 & -0.008 & $0.418^{* *}$ & $0.079 * *$ & $* *$ \\
\hline Eduservi & 0.173 & 0.016 & -0.115 & $-0.015^{*}$ & \\
\hline Eduother & -0.270 & $-0.018^{*}$ & -0.063 & -0.009 & \\
\hline Interedu & -0.100 & -0.008 & $-0.142 * *$ & $-0.020 * *$ & \\
\hline Lohigedu & -0.213 & -0.016 & $-0.383 * *$ & $-0.048 * *$ & \\
\hline Hihigedu & 0.065 & 0.006 & $-0.586 * *$ & $-0.060 * *$ & $*$ \\
\hline Creacore & 0.093 & 0.008 & $-0.148 * *$ & $-0.020 * *$ & ** \\
\hline Creaprof & $0.261 * *$ & $0.025 * *$ & $0.242 * *$ & $0.039^{* *}$ & \\
\hline Creabohe & $0.336^{*}$ & 0.037 & $0.309 * *$ & $0.055^{* *}$ & \\
\hline \multicolumn{6}{|c|}{ Family characteristics } \\
\hline Marri & $0.328 * *$ & $0.023 * *$ & $0.220 * *$ & $0.030^{* *}$ & \\
\hline Cohabit & $-0.066^{*}$ & $-0.005^{*}$ & -0.026 & -0.004 & \\
\hline Oneparen & $-0.226 * *$ & $-0.016 * *$ & -0.074 & $-0.010 *$ & * \\
\hline Childnum & 0.017 & 0.001 & 0.016 & 0.002 & \\
\hline Chilyou7 & 0.004 & 0.000 & -0.010 & -0.001 & \\
\hline Chilyou36 & 0.040 & 0.003 & -0.023 & -0.003 & \\
\hline Chilyou12 & $0.104 *$ & $0.009 *$ & -0.042 & -0.006 & * \\
\hline Chilnoco & -0.056 & -0.004 & $0.127 * *$ & $0.020 * *$ & $* *$ \\
\hline \multicolumn{6}{|c|}{ Spouse's characteristics } \\
\hline Spouentr & $0.404 * *$ & $0.045^{* *}$ & $0.758 * *$ & $0.170 * *$ & $* *$ \\
\hline Spouwagw & $-0.366 * *$ & $-0.031 * *$ & $-0.174 * *$ & $-0.025^{* *}$ & $*$ \\
\hline Spoustud & $-0.480 * *$ & $-0.026 * *$ & $-0.141 *$ & $-0.019 * *$ & * \\
\hline Spoupens & $-0.295 * *$ & $-0.019 * *$ & $-0.185 * *$ & $-0.024 * *$ & \\
\hline Spouunem & $-0.394 * *$ & $-0.024 * *$ & $-0.200 * *$ & $-0.025 * *$ & * \\
\hline Sedutrade & 0.012 & 0.001 & 0.011 & 0.002 & \\
\hline Sedutechn & $-0.138 * *$ & $-0.011 * *$ & -0.069 & -0.010 & \\
\hline Seduagric & $-0.186 * *$ & $-0.013 * *$ & -0.045 & -0.006 & \\
\hline Seduhesoc & 0.059 & 0.005 & -0.019 & -0.003 & \\
\hline Seduservi & 0.006 & 0.000 & $-0.089 *$ & $-0.012^{*}$ & \\
\hline Seduother & -0.012 & -0.001 & 0.028 & 0.004 & \\
\hline Sinteredu & $0.137 *$ & $0.012 *$ & 0.016 & 0.002 & \\
\hline Slohigedu & $0.214 * *$ & $0.020 * *$ & -0.001 & 0.000 & $* *$ \\
\hline Shihigedu & $0.290 * *$ & $0.030 * *$ & -0.014 & -0.002 & $* *$ \\
\hline Spouinco & 0.000 & 0.000 & -0.002 & 0.000 & \\
\hline
\end{tabular}


TABLE II

continued

\begin{tabular}{|c|c|c|c|c|c|}
\hline \multirow[b]{2}{*}{ Variable } & \multicolumn{2}{|c|}{ Females } & \multicolumn{2}{|c|}{ Males } & \multirow{2}{*}{$\begin{array}{l}\text { Significance } \\
\text { of the } \\
\text { difference }\end{array}$} \\
\hline & Coefficient & $\begin{array}{c}\text { Marginal } \\
\text { effect }\end{array}$ & Coefficient & $\begin{array}{c}\text { Marginal } \\
\text { effect }\end{array}$ & \\
\hline \multicolumn{6}{|c|}{ Parents' characteristics } \\
\hline Entrfat & $0.134 * *$ & $0.012 * *$ & $0.437 * *$ & $0.080 * *$ & $* *$ \\
\hline Entrmot & $0.243 * *$ & $0.024 * *$ & $0.211 * *$ & $0.035 * *$ & \\
\hline Fatinedu & $0.069 *$ & $0.006^{*}$ & -0.002 & 0.000 & $*$ \\
\hline Fathiedu & $0.098 * *$ & $0.009 * *$ & 0.018 & 0.003 & $*$ \\
\hline Motinedu & 0.028 & 0.002 & 0.000 & 0.000 & \\
\hline Mothiedu & 0.044 & 0.004 & $0.074 *$ & $0.011^{*}$ & \\
\hline \multicolumn{6}{|c|}{ House property } \\
\hline House & $0.119 * *$ & $0.009^{* *}$ & $0.158 * *$ & $0.022 * *$ & \\
\hline Housesum & $0.098 * *$ & $0.009 *$ & $0.170 * *$ & $0.027 * *$ & \\
\hline \multicolumn{6}{|c|}{ Regional characteristics } \\
\hline Native & -0.010 & -0.001 & 0.035 & $0.005^{*}$ & \\
\hline Metropol & 0.066 & 0.006 & $-0.207 * *$ & $-0.028 * *$ & \\
\hline Univreg & 0.110 & 0.010 & $-0.173 * *$ & $-0.023 * *$ & $* *$ \\
\hline Regcentre & 0.013 & 0.001 & $-0.161 * *$ & $-0.022 * *$ & \\
\hline Indcentre & 0.036 & 0.003 & $-0.242 * *$ & $-0.030 * *$ & $*$ \\
\hline Countrys & 0.002 & 0.000 & $-0.105^{*}$ & $-0.014^{*}$ & \\
\hline Densepop & 0.014 & 0.001 & $-0.242 * *$ & $-0.040 * *$ & $* *$ \\
\hline Firmavsi & -0.031 & -0.003 & $-0.031^{*}$ & $-0.004 *$ & \\
\hline Emplrate & -0.002 & 0.000 & 0.002 & 0.000 & \\
\hline Constant & -0.312 & & $-3.544 * *$ & & $*$ \\
\hline
\end{tabular}

Notes: * Significant at 5\% level; ** Significant at $1 \%$ level. Statistical testing is based on 1000 bootstrap samples. Number of observations: 146430 . Significance of the difference compares coefficients for females and males. 
TABLE III

Maximum and minimum effects of each category of variables on the probability of self-employment

\begin{tabular}{|c|c|c|c|c|c|c|c|c|}
\hline \multirow[b]{2}{*}{ Category of variables } & \multicolumn{4}{|c|}{ Females } & \multicolumn{4}{|c|}{ Males } \\
\hline & Min & Max & $R$ & $R / P$ & Min & Max & $R$ & $R / P$ \\
\hline Personal characteristics & 0.01 & 0.25 & 0.24 & 6.23 & 0.00 & 0.56 & 0.56 & 7.30 \\
\hline Family characteristics & 0.01 & 0.08 & 0.07 & 1.71 & 0.04 & 0.14 & 0.10 & 1.24 \\
\hline Spouse's characteristics & 0.01 & 0.19 & 0.18 & 4.77 & 0.05 & 0.30 & 0.25 & 3.22 \\
\hline Parents' characteristics & 0.03 & 0.09 & 0.06 & 1.59 & 0.07 & 0.23 & 0.16 & 2.05 \\
\hline House property & 0.03 & 0.05 & 0.02 & 0.50 & 0.06 & 0.11 & 0.05 & 0.65 \\
\hline Regional characteristics & 0.03 & 0.06 & 0.03 & 0.79 & 0.05 & 0.18 & 0.13 & 1.69 \\
\hline
\end{tabular}

TABLE IV

Differences in the average predicted probability of self-employment

\begin{tabular}{cc}
\hline & $\begin{array}{l}\text { Average predicted probability } \\
\text { of self-employment }\end{array}$ \\
\hline Using the estimated structural probit parameters for males & 0.102 \\
Males & 0.118 \\
Females & \\
Using the estimated structural probit parameters for females & 0.057 \\
Males & 0.052 \\
Females & \\
\hline
\end{tabular}

